\title{
Investment in Nursing Human Assets: Education and Minds of the Future
}

\author{
Maria Auxiliadora Trevizan ${ }^{1}$ \\ Isabel Amélia Costa Mendes² \\ Alessandra Mazzo ${ }^{3}$ \\ Carla Aparecida Arena Ventura ${ }^{3}$
}

This paper analyzes issues related to education, crises and changes in light of the postmodern order, emphasizing efforts towards human capital as the impetus to promote changes. Focusing on universities and organizations, we discuss the main five types of minds valued by modern and future societies, proposing investment in human assets through the use of strategies and technologies to ensure continuing education throughout life.

Descriptors: Education; Education, Continuing; Nursing; Technology.

Escola de Enfermagem de Ribeirão Preto, Universidade de São Paulo, WHO Collaborating Centre for Nursing Research Development, SP, Brazil:

${ }^{1}$ Retired Full Professor. E-mail: trevizan@eerp.usp.br.

${ }^{2}$ Full Professor. E-mail: iamendes@eerp.usp.br.

${ }^{3}$ Faculty. E-mail: amazzo@eerp.usp.br. E-mail: caaventu@eerp.usp.br.

Corresponding Author:

Maria Auxiliadora Trevizan

Universidade de São Paulo. Escola de Enfermagem de Ribeirão Preto

Dep. EGE. Sala 115

Av. dos Bandeirantes, 3900. Bairro Monte Alegre

CEP: 14040-902 Ribeirão Preto, SP, Brasil

E-mail: trevizan@eerp.usp.br 


\section{Investimento em ativos humanos da enfermagem: educação e mentes do futuro}

O objetivo deste artigo foi analisar questões sobre educação, crise e mudança à luz de tendências da nova ordem pós-moderna e dos esforços a serem empreendidos em prol do capital humano, fonte de toda energia para a concretização de mudanças. Tendo como foco as universidades e as organizações, discutem-se os cinco tipos de mentes priorizados e valorizados nas sociedades contemporâneas e do futuro, propondo-se o investimento em ativos humanos, com utilização de estratégias e tecnologias que favoreçam a garantia de educação contínua ao longo da vida.

Descritores: Educação; Educação Continuada; Enfermagem; Tecnologia.

\section{Inversiones en activos humanos de enfermería: educación y mentalidades para el futuro}

El artículo analiza: cuestiones sobre educación, crisis y cambios bajo la perspectiva las tendencias del nuevo orden postmoderno; $y$, los esfuerzos a ser emprendidos a favor del capital humano, fuente de toda la energía para la concretización de los cambios. Teniendo como foco las universidades y las organizaciones, son discutidos cinco tipos de mentalidades priorizadas y apreciadas en las sociedades contemporáneas y del futuro, proponiéndose realizar inversiones en los activos humanos utilizando tácticas y tecnologías que garanticen la educación continuada durante toda la vida.

Descriptores: Educación; Educación Continua; Enfermería; Tecnología.

\section{Education, crisis and change}

The generalized concept of education is the transmission and learning of cultural techniques, that is, techniques of use, production and behavior, through which individuals become competent to "meet their needs, protect themselves against hostility in the physical and biological environment and work in groups, in a more or less organized and peaceful manner"(1). Hence, we have a human society that cannot exist if its culture is not transferred from generation to generation. The principles that enable and concretize this transmission are provided by education. This generalized concept of education is essential in both primitive and civilized societies. Although the modalities of education in distinct societies are not different in relation to their development, they differ in relation to the adopted attitude or orientation. In a primitive society, education seeks to ensure the maintenance of work techniques, attributing to them a sacred character, ensuring their relative immutability and considering any innovating idea profane. A civilized society on the other hand, is conveniently prepared to face new situations and to change. Thus, the function of education in this context is to improve the techniques used, make them more flexible and correctable and also to disseminate, through appropriate means, new content. It is worth highlighting that in the same way there is no primitive society in a pure state, there is not either a civilized society that favors rapid and constant improvement of more delicate techniques, that is, those that refer to the conduct of individuals and their mutual behaviors. In civilization, the dissemination of already adopted techniques enables its improvement through the initiative of people. As a result, education starts to be defined from the standpoint of the individual and not from that of society: it aims for the education of human beings, the maturation of individuals and the achievement of its complete form as a gradual path departing and going from potential to the act of realization ${ }^{(1)}$.

Our civilization is currently in a convergence of crises affecting the family, urban life, politics, values, teaching and health systems. Considering that crises 
represent a transition and that these need to be faced as opportunities to change, we have to adopt a proactive attitude to guide and structure such changes, taking practical measures to conduct them. As a consequence of this expected coping, an emergent civilization carries a changed consciousness and seeks a differentiated system of behavior based on the view of a synthesis of the whole. With this new view emerge specific and innovating ways of conceiving and using "time, space, logic and cause-effect relationships", making it possible to establish guidelines for future polices ${ }^{(2)}$.

The trends of this new postmodern order reflect on nursing work and services and an effort should be made to overcome the status quo, since the source of all energy to concretize change originates in human capital. It brings us to the social responsibility that universities and health organizations and services have in view of citizens.

\section{University, Organization and Minds of the Future}

Howard Gardner, through psychology, anthropology and other disciplines in the human sciences, developed a description of minds associated with an undertaking of human values, given the types of minds people will need to progress in emergent times. In other words, the author specifies the functions of minds that will be needed, recommending their development in view of new skills that come to be required by the nature of the interconnected world in which we live, with its search mechanisms, digital tools and diverse computer devices ${ }^{(3)}$.

We believe that universities are organizations conducive to answer this call, capable of developing cognitive skills inserted in the types of minds, described by the author, to train and educate citizens, driven by changes in the job market, production of knowledge and public policies(4).

From Gardner, we have the following types of minds: the disciplined mind, the synthesizing mind, the creative mind, the respectful mind and finally the ethical mind. The first refers to learning about how to think in a disciplined manner. The disciplined mind prepares a person for professional practice. From this perspective, educational initiatives seek disciplinary knowledge, mental habits and standards of appropriate behavior such as the objective "to eradicate erroneous and unproductive ways of thinking and replace them with ways of thinking and doing characteristic of a disciplined professional." It enables the maturation of a judicious development of planning, execution, critique and evaluation skills. Through discipline it is possible to train a person to improve a certain skill. It can also enrich the individual's view through systematized and disciplined observation.

The synthesizing mind learns and objectively evaluates information received from different sources. It synthesizes current knowledge, the incorporation of new discoveries and delineation of new problems and perspectives that integrate its professional field. The synthesizing mind aims to focus on what is already established in the most useful and comprehensive way. It seeks order and balance. The most ambitious synthesis occurs in interdisciplinary work ${ }^{(3)}$. In general, the integration of disciplines produces an understanding different from that obtained from only one discipline, enabling interdisciplinary professionals to have a more comprehensive perspective of reality.

Creativity is highly valued and encouraged in modern society. The creative mind has the ability to break barriers, present new ideas, propose questions and innovate, evocate the unknown, and also revea and solve new problems. For the author, some of the best creations originate in attempts to synthesize. The creative mind is motivated by uncertainty and constant challenge and is not bounded by predetermined rules, rather it pursues the new, the unexpected. This type of mind seeks to keep ahead of the latest in technological, professional and even behavioral terms. It pursues new knowledge. It is an uncommon mind and much sought after in leaders. Significant and constant changes, even if small, are greatly desired in professional practice.

The respectful mind originates in consciousness, in the understanding and acknowledgment of differences existent among human beings. This type of mind recognizes the importance of diversity and seeks to work efficiently with it. It tries to perceive people as they are, offering and inspiring trust.

The ethical mind works at a level more abstract than the respectful mind. It aims to comply with its own responsibilities as a worker and citizen. In other words, this mind determines, in a conceptual dimension, the way workers comply with their responsibilities overcoming their own interests and establishing how citizens can work towards the common good. Ethical behavior implies strength of character.

The author stresses that the five minds are the main minds valued in modern society and that will be valued in any future society. The first three types of minds cover 
the cognitive spectrum and human enterprise since they are comprehensive and global. The remaining types of mind are confined to our relationships with other human beings.

\section{Investment in human assets}

Having discussed education, crisis and change, and appealed to the five minds suggested by Gardner, we assert that these mental skills can be better developed within universities in order to train and educate citizens, taking into account that business organizations are also environments conducive to improving skills related to the five minds of the future. Hence, we now suggest strategies to achieve such a goal.

From this perspective, two simultaneous strategies have been satisfactory in countries that seek to synchronize education with changes in the context that surrounds them. These strategies aim to transform current education in two ways:

- making continuous education available to citizens over their lives through the institutionalization of networks;

- adopting the distance education model and thereby distributing opportunities for people to access learning.

This conception of education included in these two strategies, requires a reorganization of the school and its educational processes, as it implies a key shift in mission involving extension, duration and scope. The new education aims to include all people in all phases of life permanently. If used this way, this new education can answer to the challenges imposed by changes in society such as: globalization, technological and scientific revolutions with the increasingly rapid incorporation of knowledge in all fields of human activities, social responses as reflexivity, socialization and transformation in the job market. This in turn generates demands for the development of citizens' personal and professional competencies $^{(4)}$.

What mobilizes these forces and resulting changes is that they "operate with unprecedented power not only because they are after objective needs of the productive system but also because they are empowered by great social and cultural legitimacy. In fact, they emerge as forces inherent to modernity, as demands originating from emerging groups, identified with knowledge, with the information society, with globalization and functions considered more prestigious"(5).

Innovating projects of continuous education in nursing work should meet criteria and measures that favor individuals' understanding in the process of improvement, enabling creative and reflective ways of thinking in order to enable citizens-workers to develop personally, socially and professionally.

Continuous education enhances personal development through technical training, acquisition of new knowledge and concepts, which should be translated into attitudes and keep a close relationship between the training and work processes. It also enables social development as a result of constant learning of individuals based on their relationships. Education is, therefore, part of an individual's life as $s /$ he exercises autonomy and the ability to learn, resulting in the development of citizens in their context of work $^{(4,6-7)}$.

In summary, this way of implementing continuous education should seek, above all, the meaning of learning to learn and enable subjects to acquire full awareness concerning the importance of this type of continuous education $^{(8)}$.

From this perspective, health education is an important tool to permanently construct and reconstruct skills and competencies, allowing a broader understanding of health practice, with an increased ability to analyze and intervene in the different processes that result from it, encouraging changes of valorization and humanization in the relationships between the involved subjects $^{(9-11)}$.

Therefore, education and health are interdependent processes, social needs that should be grounded on institutional leadership, political power and networks of cooperation that constitute elements that found the development of a technological base for health

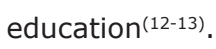

In all aspects of life in the global culture, things move faster. People now have an expectation and an increasing desire for speed in all facets of their lives. Thus, if one wants to prosper in a world defined by speed, one needs to turn the power of speed to one's favor(14-15).

Using the speed technology provides in the health field means that we should use computers, mouse clicks and distance learning to develop, enhance and integrate human resources, which is itself the most valuable commodity societies have to provide care, promote and educate in health. There is no use having techniques, financial resources and power if we do not have functional health systems and ensure free accessibility through productivity, quality, equity and social justice.

Nurses integrate a profession, which is considered the backbone of health systems, not only because of 
their large representation (their work force is equal to or greater than $75 \%$ among health workers) but also due to the need to have this professional permanently (24 hours) available in the various services, coordinating care and serving as a link within the health team.

Let us use continuous education over the course of life and technology to promote these valuable human resources with the appropriate methodology because individuals should be committed to continuous education throughout life so they are able to offer quality health services to a population that demands and deserves it.

Finally, it is important that nursing can count on professionals familiar with mental skills related to discipline, creativity, respect and ethics, which will guide their knowledge, their enterprise in serving, as well as their relationships with others.

\section{References}

1. Abbagnano N. Dicionário de Filosofia. 4. ed. São Paulo (SP): Martins Fontes; 2000. p. 305-6.

2. Toffler A, Toffler H. Criando uma nova civilização: a política da terceira onda. 7. ed. Rio de Janeiro (RJ): Record; 2003.

3. Gardner H. Cinco mentes para o futuro. Porto Alegre (RS): Artmed; 2007.

4. Brunner JJ. Educação no encontro com as novas tecnologias. In Tedesco JC. Educação e Novas Tecnologias: esperança ou incerteza? São Paulo (SP): Cortez; 2004. p. 17-75.

5. Laluna MC, Ferraz CA. Os sentidos da prática avaliativa na formação. Rev. Latino-Am. Enfermagem. [internet]. 2009. [acesso em: 20 dez 2009]; 17(1):21-7 Disponível em: http:// www.scielo.br/scielo.php?script=sci_arttext\&pid=S0104-11692 009000100004\&lng=en\&nrm=iso\&tlng=pt

6. Paschoal AS, Mantovani MF, Méier MJ. Percepção da educação permanente, continuada e em serviço para enfermeiros de um hospital de ensino. Rev Esc Enferm USP. [internet]. 2007. [acessado em: $18 \mathrm{dez} 2009] ; 41(3): 478-84$. Disponível em: http://www.scielo.br/scielo.php?script=sci_arttext\&pid=S008062342007000300019

7. Muforose NT, Rizzoto MLF, Muzzolon ABF, Nicola AF. Diagnóstico da situação dos trabalhadores em saúde e o processo de formação no pólo regional educação permanente em saúde. Rev. LatinoAm. Enfermagem. [internet]. 2009. [acessado em: 19 dezembro 2009]; 17(3):314-20. Disponível em: http//www.scielo.br/scielo. php?script=sci_arttext\&pid=So104-11692009000300006\&lng

8. Ricaldoni CAC, Sena, RR. Educação permanente: uma ferramenta para pensar e agir no trabalho de enfermagem. Rev. Latino-Am. Enfermagem. [internet]. 2006. [acesso em: 12 jun 2009]; 14(6):837-42. Disponível em http://www.scielo. br/scielo.php?pid=S0104-11692006000600002\&script $=$ sci $_{-}$ abstract\&tlng $=$ pt
9. Santos-Filho SB. Perspectivas da avaliação na Política Nacional de Humanização em Saúde: aspectos conceituais e metodológicos. Ciênc Saúde Colet [internet]. 2007. [acesso em: 10 jun 2009]; 17(3):999-2010. Disponível em: http//www.scielosp.org/scielo. php?pid=S1413-1232007000400021\&script=sci_arttext\&tlng= 10. Silva $K L$, Sena RR. Integralidade do cuidado na saúde: indicações a partir da formação do enfermeiro. Rev Esc Enferm USP. [internet]. 2008. [acesso em: $18 \mathrm{dez}$ 2009]; 42(1):4856. Disponível em http://www.scielo.br/scielo.php?pid=S0080$6234008000100007 \&$ script $=$ sci_arttext $\&$ tIng $=$ pt

11. Pasche DF. Política Nacional de Humanização como aposta na produção coletiva de mudanças nos modos de gerir e cuidar. Interface. 2009; 13 Suppl. 1:701-8.

12. Rodríguez CA, Kolling MG, Mesquita P. Educação e saúde: um binômio que merece ser resgatado. Rev Bras. Educ Med. [internet]. 2007. [acesso em: 10 jun 2009]; 14(6):60-6. Disponível em: http://www.scielo.br/scielo.php?script=sci_arttext\&pid=S0100-5 5022007000100009\&tlng=en\&lng =en\&nrm=isso

13. Cavalcante MTL, Vasconcellos MM. Tecnologia de informação para a educação na saúde: duas revisões e uma proposta. Cienc Saúde Colet. [internet]. 2007. [acesso em: 10 jun 2009]; 12(3):611-622 Disponível em http://www. scielosp.org/scielo.php?script=sci_arttext\&pid=S1413$81232007000300011 \& \mathrm{lng}=\mathrm{pt}$

14. Poscente V. A era da velocidade: aprendendo a prosperar em um universo mais-rápido-já. Trad. Suely Cuccio. São Paulo (SP); DVS Editora, 2008.

15. Barbosa SFF, Marin HF. Simulação baseada na WEB: uma ferramenta para o ensino de enfermagem em terapia intensiva. Rev. Latino-Am. Enfermagem. [internet]. 2009 [Acesso em: 18 dez 2009]; 17(1):7-13. Disponível em: http://www.scielo.br/ scielo.php?script=sci_arttext $\&$ pid $=$ S0104-11692009000100002 \&lng $=$ en\&nrm $=$ iso\&tlng $=p t$

Received: Jul. 21 2009

Accepted: Apr. $16^{\text {th }} 2010$ 